\title{
Research on Responsibilities of Human Resources Management for Non-human Resources Manager
}

\author{
Li-Jing WANG \\ Beijing Youth Politics College, 100102 \\ wanglijing@bjypc.edu.cn
}

\begin{abstract}
Keywords: Non-Human resources manager, Human resources management, Specific responsibilities.
\end{abstract}
\begin{abstract}
Human Resource Management of enterprise is a systematic engineering. In actual work, the Non-Human Resources department undertakes execution function of Human Resource Management to a certain extent. Therefore, clearing responsibilities of Human Resources Management for Non-Human Resources manager, and strengthening training for Non-Human Resources manager, have become one of the important ways to improve and raise the level of Human Resource Management. First, this paper puts forward the problem. Second, the author investigates duties of Human Resources Management for Non-Human Resources manager by questionnaire investigation and literature analysis. Last, this paper defines responsibilities of Human Resources Management for Non-Human Resources manager.
\end{abstract}

\section{Raise a question}

First, it is emphasized that Non-Human Resources department is referred to other departments in addition to Human Resources department in the enterprise, and Non-Human Resources manager is referred to other department manager in addition to Human Resources manager in the enterprise in this article.

According to the views of system theory, Human Resources Management in the enterprise is a systematic project, and all departments should participate. In fact, in an enterprise, department manager is the direct manager of the employees, and his management level affects directly enthusiasm and performance of the employees. Before, we think generally that Human Resource Management is related to Human Resources department, not related to other department. In fact, a lot of specific work of Human Resource Management is organized and implemented by Non-Human Resources department. That is to say, no matter what which department managers, their work will involve staff selection, training, evaluation, compensation, rewards and punishments, etc. As you see, Human Resource Management is not only the job of Human Resources department, but also related to all the managers in the enterprise. Human Resources Management is deemed to the responsibilities of each manager in the enterprise.

\section{Analysis on the results of survey}

We investigated from 21 Non-Human Resource managers by questionnaires and interviews, to systematically understand their responsibilities of Human Resource Management in the practical work. The following is the results of investigation and analysis.

\section{Responsibilities about recruitment and selection of the employee}

The result of investigation about responsibilities of recruitment and selection of the employee is shown in table 1.

Table 1 Responsibilities about recruitment and selection of the employee

\begin{tabular}{|l|c|}
\hline \multicolumn{1}{|c|}{ Main responsibilities } & percentage \\
\hline Report the information of the employment demands to human resources department & $71.4 \%$ \\
\hline Make sure the candidates of interview or written examination & $52.4 \%$ \\
\hline Participate in specific interview & $71.4 \%$ \\
\hline Interview assessment & $76.2 \%$ \\
\hline Put forward suggestions for the recruitment & $71.4 \%$ \\
\hline
\end{tabular}




\section{Responsibilities about training and development of the employee}

The result of investigation about responsibilities of training and development of the employee is shown in table 2 .

Table 2 Responsibilities about training and development of the employee

\begin{tabular}{|l|c|}
\hline \multicolumn{1}{|c|}{ Main responsibilities } & percentage \\
\hline Give the professional guidance of the employee of department & $85.7 \%$ \\
\hline Put forward training needs to human resources department & $57.1 \%$ \\
\hline Train the employee personally & $66.7 \%$ \\
\hline Participate in making training plan of the company & $42.9 \%$ \\
\hline
\end{tabular}

\section{Responsibilities about performance assessment of the employee}

The result of investigation about responsibilities of performance assessment of the employee is shown in table 3.

Table 3 Responsibilities about performance assessment of the employee

\begin{tabular}{|l|c|}
\hline \multicolumn{1}{|c|}{ Main responsibilities } & percentage \\
\hline Assess the employees of the department personally & $61.9 \%$ \\
\hline Talk about performance with the employees & $57.1 \%$ \\
\hline $\begin{array}{l}\text { Set standards of performance appraisal of the employees of the } \\
\text { department }\end{array}$ & $52.4 \%$ \\
\hline
\end{tabular}

\section{Responsibilities about compensation management of the employee}

The result of investigation about responsibilities of compensation management of the employee is shown in table 4.

Table 4 Responsibilities about compensation management of the employee

\begin{tabular}{|l|c|}
\hline \multicolumn{1}{|c|}{ Main responsibilities } & percentage \\
\hline $\begin{array}{l}\text { Make Suggestions on salary adjustment of the staff of the } \\
\text { department }\end{array}$ & $57.1 \%$ \\
\hline $\begin{array}{l}\text { Participate in discussing compensation system reform scheme of } \\
\text { the company }\end{array}$ & $52.4 \%$ \\
\hline Put forward suggestions in terms of welfare distribution & $52.4 \%$ \\
\hline Assist in making scheme of bonus distribution & $42.9 \%$ \\
\hline
\end{tabular}

\section{Responsibilities about job analysis}

The result of investigation about responsibilities of job analysis is shown in table 5 .

Table 5 Responsibilities about job analysis

\begin{tabular}{|l|c|}
\hline \multicolumn{1}{|c|}{ Main responsibilities } & percentage \\
\hline Adjust responsibility of job & $71.4 \%$ \\
\hline Adjust qualifications & $61.9 \%$ \\
\hline Dissolution or merger of post & $57.1 \%$ \\
\hline Revise job description & $57.1 \%$ \\
\hline
\end{tabular}

\section{Responsibilities about labor relations management}

The result of investigation about responsibilities of labor relations management of the employee 
is shown in table 6 .

Table 6 Responsibilities about labor relations management

\begin{tabular}{|l|c|}
\hline \multicolumn{1}{|c|}{ Main responsibilities } & percentage \\
\hline Encourage superior employees to renew the labor contract & $71.4 \%$ \\
\hline Put forward suggestion on dismissing inferior employee & $66.7 \%$ \\
\hline $\begin{array}{l}\text { Put forward suggestion on transforming the post of inferior } \\
\text { employee }\end{array}$ & $47.6 \%$ \\
\hline
\end{tabular}

In addition, we also investigated about daily incentive ways by Human Resources manager and whether to need to plan personnel demand of this department.

Through the survey, we found that daily incentive ways by Human Resource managers include mainly: praise and admire the employee timely; take care for the staff; stimulate by bonuses; stimulate by job goal; arrange the challenging tasks; train and guide your subordinates; concern about the growth of the employees, etc. These incentive ways are chose by the proportion of more than 50 percent.

Asked whether Non-Human Resources managers should plan personnel needs of this department, managers of 76.2 percent agree. Therefore, it is one of responsibilities that Non-Human Resource managers should assume.

\section{Literature review}

About responsibilities of Human Resources Management for Non-Human Resources manager, domestic scholars have done some research, but research result is few. At present, there are a lot of related training course, but related research don't rise to the theoretical level, and it can't be added to Human Resources Management theory system. The following is some viewpoint of domestic scholars.

Chen Rihua thinks that Non-Human Resources manager should undertake responsibilities of Human Resources Management in talent selection, talent cultivation, effectively motivate subordinates, team building, employee relationship management, proper authorization, etc.

Zhao Lin thinks that Non-Human Resources department should cooperate with the Human Resources department in recruitment, selection, training, assessment, etc. At the same time, it respects the professionalism rules of human resources department of the company, and is responsible for the department and employees, cultivates employees' loyalty to the organization, etc.

Xiong Kan proposes specific duties of Non-Human Resources manager from clearing positioning of the departments, personnel allocation, organization optimization, selection, motivation, evaluation, training, elimination, communication and collaboration, and so on.

To sum up, responsibilities of Human Resources Management for Non-Human Resources manager are mainly concentrated in job analysis, Human Resources planning, recruitment and selection, training, evaluation, motivation, team building, etc. Therefore, we think that Non-Human Resources manager will also play a role of Human Resources manager in the practical work of the department.

\section{Conclusion}

Through above results of questionnaires and interview investigation and literature research, responsibilities of Human Resources Management for Non-Human Resources manager are taken the following definition in this paper. To be sure, the author just defines in allusion to common situation, and it is not a strict demarcation because each enterprise gives different authority and responsibility to Non-Human Resources manager. The viewpoint of this paper is shown in table 7. 
Table 7 list of responsibilities of Human Resources Management for Non-Human Resources manager

\begin{tabular}{|c|c|}
\hline work module & Specific job responsibilities \\
\hline Job analysis & $\begin{array}{l}\text { 1. For the newly established enterprises, To be responsible or } \\
\text { assist to complete writing of job description of each post in the } \\
\text { department } \\
\text { 2. puts forward requirements of job analysis, and assist to revise } \\
\text { job description with changes in the work } \\
\text { 3.Further define responsibilities and qualifications of each } \\
\text { position }\end{array}$ \\
\hline $\begin{array}{l}\text { Human Resource } \\
\text { planning }\end{array}$ & $\begin{array}{l}\text { 1. Responsible for personnel demand forecasts of the department, } \\
\text { and completes Human Resources planning } \\
\text { 2. Assist to finish capacity allocation of the department } \\
\text { 3. Have personnel configuration and flow reasonably }\end{array}$ \\
\hline $\begin{array}{l}\text { Recruitment and } \\
\text { selection }\end{array}$ & $\begin{array}{l}\text { 1. Report the information of persons demand to Human Resources } \\
\text { department } \\
\text { 2.Participate in filtrating initially by screening applicants } \\
\text { materials, make sure the candidates of interview or written } \\
\text { examination } \\
\text { 3. Participate in specific interview } \\
\text { 4. Evaluate the interview } \\
\text { 5. Suggest recruitment }\end{array}$ \\
\hline training & $\begin{array}{l}\text { 1.Put forward needs of training to Human Resources department } \\
\text { 2.Be responsible for training the staff about business knowledge, } \\
\text { skills, attitudes, and communication skills, giving employees } \\
\text { some training or instruction }\end{array}$ \\
\hline stimulation & $\begin{array}{l}\text { 1.praise and admire the employee timely } \\
\text { 2.Pay attention to the life and personal growth of the employees } \\
\text { 3. strengthen the daily communication } \\
\text { 4.arrange some challenging tasks } \\
\text { 5. Give employees some guidance or advice }\end{array}$ \\
\hline $\begin{array}{l}\text { Assessment } \\
\text { management }\end{array}$ & $\begin{array}{l}1 \text { assist to set performance assessment standards with Human } \\
\text { Resources department } \\
\text { 2. Organize and implement assessment } \\
\text { 3. Responsible for assessing the staff of the department } \\
\text { 4. Tall the employees about their assessment result } \\
\text { 5.Interview with employees, and help employees make } \\
\text { performance improvement plan }\end{array}$ \\
\hline $\begin{array}{l}\text { compensation } \\
\text { management }\end{array}$ & $\begin{array}{l}\text { 1. Participate in discussing compensation system reform scheme } \\
\text { of the company } \\
\text { 2. Put forward Suggestions on welfare distribution; } \\
\text { 3. suggest about salary adjustment of the staff of the department }\end{array}$ \\
\hline $\begin{array}{l}\text { Employee } \\
\text { relationship } \\
\text { management }\end{array}$ & $\begin{array}{l}\text { 1. Put forward suggestion on dismissing unsatisfied employee } \\
\text { 2. Encourage excellent employees to renew the labor contract }\end{array}$ \\
\hline
\end{tabular}

\section{References}

[1] Zhou Changxiang. Human Resources Management for Non-Human Resources manager [M]. Guangzhou: Guangdong economic press, 2010.9.

[2] Chen Rihua. Responsibilities of Human Resources Management for Non-Human Resources 
manager [J]. Journal of China Human Resources development, 2011 (3).

[3] Sun Lihu. Human Resources Management for Non-Human Resources manager [J]. Journal of Taiyuan university, 2009 (3).

[4] Li Peifeng. How to manage Human Resources for Non-Human Resource manager[J]. Journal of Human Resource Management, 2009 (1). 